\title{
Investigating Intermediaries that Participate in Internet Commerce to Determine the Elements of Online Price Dispersion
}

\author{
Mahmoodreza Arefi ${ }^{1}$, Amir Masoud Amini ${ }^{2}$ \\ Tarbiat Modares University ${ }^{1}$, Mapna Group ${ }^{2}$
}

\begin{abstract}
Frictionless electronic commerce is a made-up story and online price dispersion is high and steady. There is not enough proof that online prices are decreasing and becoming alike. Although the studies show that prices dispersion on the Internet is decreased, they are steady yet. Therefore, this study aims to determine the important dimensions of electronic retailers' heterogeneity and examine the markets elements that influence price dispersion. The rapid development of e-commerce in Iran has made this task feasible.

Questionnaire and observation were the methods used for collecting the data in this study. 106 identical products from 56 electronic retailers and 948 price quotes in different products categories such as books, CDs, laptops, mobiles, monitors, MP3s and digital cameras in online market have been used as data. 140 questionnaires have been developed for evaluating electronic retailers' characteristics. The method used in this analysis is statistical which mostly were factor analysis, cluster and regression analyses.

It has been proved that services provided by electronic retailers could be described by five basic factors. Average price level of items and increase in the number of competitors, increase and decrease price dispersion respectively. Over $85 \%$ of the variance in price dispersion is explained through the model.
\end{abstract}

\section{Introduction}

E-commerce is capable of bringing a revolution in the interaction between individuals and organization.

Increased market access and decreased operating and procurement costs are among the efficacies provided by e-commerce for retailers. On the other hand, consumers access to more extended information on goods and services and benefit from products customization, greater shopping convenience, increased choice of products and enhanced price competition.
E-commerce and specifically electronic retailing have lead to series of studies on online price dispersion. Online price dispersion means the difference in prices of an item with the same features across the online sellers of that item in certain point of time.

The statistics from "Internet world stats" website demonstrate that the number of Internet users in Iran has drastically increased from 250,000 users in 2000 to 23 million users in 2008 year which shows about 92 times growth. The rapid growth of Internet provides the opportunity to survey the elements influencing the online price dispersion.

Online price dispersion deserves examination and study because of its possible future effect on modeling consumer and producer behavior and policy. Price dispersion is important concerning consumers, sellers, and the market as a whole. Price dispersion means alternative offerings in the market for consumers and will therefore influence their search and purchase behavior. And it's a mirror of competitors' pricing strategy and their interactions for sellers. And it also shows the level of information efficiency in the market.

Since frictionless economy is a made-up story $[1,2]$, it is a generally accepted idea that online price dispersion is an important subject. There are some elements for this dispersion. Since online markets have grown dramatically in Iran recently, the elements influencing online price markets are being studied. According to some studies [3], no variance is seen in online price dispersion over time.

Online price dispersion and the elements influencing them should be studied considering a number of different products sold in online markets to be able to identify the drivers of online price dispersion which is the main purpose of this study.

There are several elements that are identified to have influence in offline market such as incomplete information [4], not a consistent price setting due to 
menu cost [5], uncertainty demand, costly capacity and setting of price [6]. Although many theoretical discussions have been held about potential elements influencing price dispersion, very few empirical studies have been carried in this area.

Different kinds of influencing elements have been identified in these studies. According to Clemons, Eric Hann, and Hitt [7], online price dispersion is the result of price discrimination caused by marketers. Lower price sensitivity and thus difference in prices could be caused by difference in information content, (Shanker, Rangaswamy and Pusateri [8]. According to Smith, Bailey and Brynjolfsson [9], heterogeneity in features of services provided by electronic retailers is the main cause of online price dispersion. The studies carried by Pan, Ratchford and Shankar [10]suggest that online price dispersion is explicable through electronic retailers' characteristics, market characteristics and product differences.

We conclude that although there are several explanations for online price dispersion, not enough empirical work has been done on the influencing elements on online markets in IRAN. Understanding the phenomenon of online price dispersion depends heavily on such empirical work.

The probable influencing elements on online price dispersion are discussed in the next section. Research questions and model formulation are explained in section 3 and 4 respectively. Data and the measurement and analysis the data are discussed in section 5. The result is presented in the subsequent section.

\section{Literature Review}

Smith, Bailey, and Brynjolfsson [11] enumerate the possible elements effecting price dispersion in online markets: diversity of product, shopping suitability, consumer awareness of the seller's existence, branding and trust provided by electronic retailer that decrease consumer risks, make any change in costs impossible, and difference in prices. Generally, these sources and other additional influencing elements could be categorized into two groups: (1) electronic retailer characteristics and (2) market characteristics. This is done after checking differences in product category [12]. Here we explain the effects of these elements on electronic retailer prices and price dispersion.

\subsection{E-Tailer Characteristics}

Shopping convenience: variety of shopping suitability might affect price dispersion. Feasibility of finding and evaluating with the help of more qualified search tools, navigation and faster checkout make it possible to search far less and bear less costs. In this way, by offering more qualified services, one can profit more [13]. Then there it is expected to be relevance between price dispersion and difference in shopping suitability.

Reliability in fulfillment: price dispersion of a product could be influenced by differences in reliability in electronic retailer's work. Reliability depends on the following factors: delivery time, whether the product was delivered as promised, and consistency of customer service. As buyers and sellers in online markets do not deal in the same place and time, the transaction does not happen at exactly the same time, and this makes customers to worried whether they would receive the product they buy online [14]. Therefore, the more an electronic retailer reliable is, the higher prices he can charge.

Product information: if websites provide users with high quality information about product, the sensitivity about online price decreases [15]. The electronic retailers who provide deeper information are more successful in decreasing price sensitivity and charging higher prices.

Shipping and handling: electronic retailer prices could also be affected by Shipping and handling service. There are consumers who put value at high quality for shipping and handling services and the electronic retailers who satisfy such customers would be able to charge higher prices.

Pricing policy: electronic retailer with whatever financial policy, need to consider this factor important in diversity. There are some retailers who are able to offer blow marginal cost and bear some loss at the beginning to profit in the future [16]. Others may not. It is expected that electronic retailer who believe on the higher prices than usual, have higher prices. Therefore, diversity in pricing policy should be related to price dispersion.

Inventory position: price for an item could be determined by this factor. It seems that the higher the level of this factor is, the lower the price would be. As it could differ for different items in the same retailer, could not be an attribute for electronic retailer services. But it is expected to have relevance with price dispersion.

Time of online market entry: Schmalensee[17] have discussed the advantage that the early mover enjoyed in conventional market and their online counterpart have the same status, though not mentioned that much. According to Geyskens, Gielens and Dekimpe [18] the beginners perform better. Therefore, the later they are, the lower the price is expected. It could be reasoned that price dispersion increase as the time interval between sequential online market increases. 
E-Tailer Trust and Branding: brand and trust can decrease consumers' worry. When the products are same, brand [19] and loyalty [20] play an important role in customers' choice. Providing satisfying experience through third party recommendation is the key to brand and trust among consumers. Therefore, price dispersion could be affected by brand and trust factors.

Consumer awareness: the great difference between traditional and online market is the amount of information the retailer offer about product. Online markets enjoy price comparison engines such as Bizrate.com [21]. The consumers should of course be aware of these engines. Therefore, e-tailors which provide more information and awareness and could enjoy higher price.

\subsection{Market Characteristics}

Number of competitors in a market: competitiveness has already been examined in offline price dispersion [22]. According to Carlson and McAfee [23], there is an inverse proportion between the number of competitors and price dispersion. But this was not the case in Dahlby and West [24] Test. They applied the model offered by Carlson and McAfee in insurance market and found that price dispersion increase by competitors increasing. This inconsistency remained unexplained. Cohen [25] believes that the number of alternatives in a market functions conflict as "a double-edged sword." On the one hand, the more the number of alternative is, the higher the competitiveness and the less price dispersion are.

Consumer involvement: Search behavior of consumers influences their involvement level [26]. The more they are involved, the more they take time for searching because they understand the benefits they could receive by searching. The term "involvement" in the marketing literature means "utility level", i.e. "price level" or "financial outlay" [27]. Therefore, as the search models predict, there should be less price dispersion in expensive product category. But the evidence is not clear. Cohen's [28] findings verify this prediction but those of Pratt, Wise and Zeckhauser [29] do not. Therefore, to know the exact effect of consumer involvement on price dispersion, we should further our research.

Popularity of the product item among consumers: the products that are well accepted and purchased by many consumers are considered popular. Online markets depend heavily on word of mouth marketing. Consumers tell their friend about the products they like through news groups, chat room, etc. the more popular a product, the more information is exchanged among consumers about it. Therefore, it is expected that price dispersion be lower for more popular products.

\subsection{Products category differences}

Hedonic price regression method was used in previous studies to check product diversity. For example, arrival and departure times, number of connections, and Saturday night stays are the elements studied in variation in airline ticket prices by Clemons, Hann, and Hitt [30]. Despite controlling these sources of heterogeneity, price dispersion found to be still important. However, the aspects such as meal offering and refund policy were not considered in the model. Therefore, to omit unmeasured product heterogeneity, other studies on homogeneous products, such as books, CDs, DVDs, electronics, computer hardware and software is needed. Price dispersion could be different for different product categories.

Despite controlling the price level of different product categories, they could have different levels of price dispersion. For example, products with high consumer awareness might have lower price dispersion. But we could not deal with such effects in this study. Therefore, we use dummy variables to check potential category differences.

\section{Problem Statement}

Research Question (1): What are the some key dimensions of e-tailer heterogeneity? This question is based on major underlying dimensions of e-tail services which are ease of ordering, product selection, product information, price, web site navigation and looks, On time delivery, product representation, level and quality of customer support, tracking and shipping and handling factors which are used by Bizrate.com, Motorola.com, shopper.com and shopping.com. It is used by previous researches [31]

Research Question (2): How product, market characteristics and e-tailer characteristics effect on the prices of homogeneous goods sold on the Internet? (Drivers of online dispersion)We can classify these sources and other additional drivers of online price dispersion into two sets of factors, namely, (1) e-tailer characteristics and (2) market characteristics, after controlling for product category differences. It is defined by previous research [32].

\section{Research Model}

First, we factor analyze the e-tailer services to identify the major underlying dimensions of e-tail services; factor scores based on these ratings provide the service measures used as independent variables in our analysis of price dispersion. Second, in order to 
identify the competitive positioning of e-tailers on these service clusters analysis of these factor scores is done. Third, we use a set of regressions linking price dispersion measure to variation in e-tailer and in market characteristics to investigate the drivers of price dispersion. In order to test the e-tailer, market characteristics and product category on price we applied the comprehensive model which introduced by Pan, Ratchford and Shankar 2003 in figure1.

\section{Data Gathering and Analysis}

To avoid the potential problem of unmeasured product heterogeneity, it is focused deliberately on identical products such as books, CDs, laptop, mobile, monitor, mp3, Digital camera. We collected 948 price quotes for 106 identical products form 56 e-tailers during 2007 year. For example, the Dell laptop computer with features $\mathrm{P} 4,1800 \mathrm{MHZ}$ processor,512
MB memory,120 GB hard disk, 8x DVD, 56Kbps modem and 15.1 screen, sold by one e-tailer is the same sold by another.

Ten aspects of e-tailers services are evaluated using a five-point scale and an overall measure of the average of the ten measure is also provided. In Table 1 the ten measures used by Bizrate.com are listed and explained. Online markets such as shopper.com, shopping.com and price.com use these ratings widely. Inventory position is also measured by percentage of on-time shipments from the electronic retailer.

\subsection{Factor Analysis}

From the ten measures studied for all electronic retailers by applying factor analysis method, five of them shown to explain $81.5 \%$ of the variance. Tables 2 provide the component matrix obtained using Equimax rotation respectively.

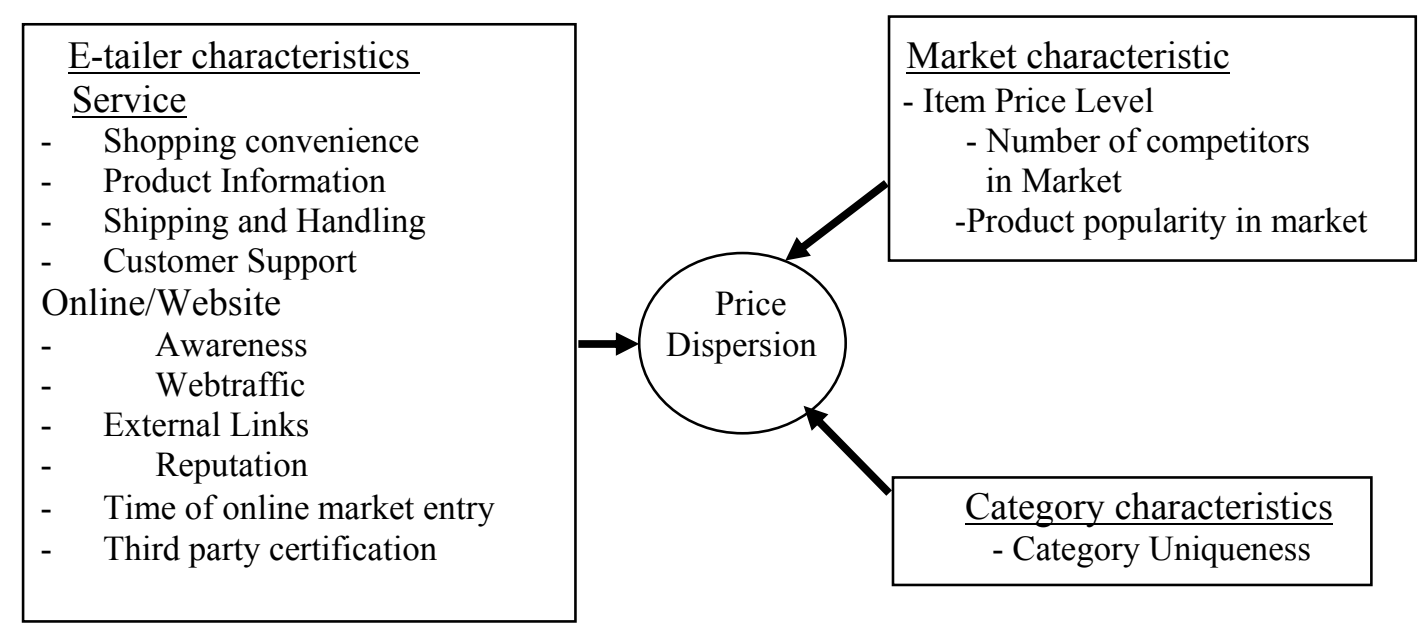

Figure 1: Research Model

Table 1. Explanation of Measures of E-Tailers Features

\begin{tabular}{|c|l|}
\hline Measure & \multicolumn{1}{|c|}{ Explanation } \\
\hline Ease of Ordering & Conveniece and speed of ordering \\
\hline Product Selection & Breadth of products offered \\
\hline Product Information & Information quantity, quality and relevance \\
\hline Price & Price relative to similar stores \\
\hline Web site navigation and looks & Layout links pictures images and speed \\
\hline On Time Delivery & Expected vs actual delivery date \\
\hline Product Representation & Product description vs. what was received \\
\hline Level and Quality of Customer Support & Status updates and complaint/ question handling \\
\hline Tracking & Tracking order status \\
\hline Shipping and Handling & Shipping and handling charges and options \\
\hline
\end{tabular}


The analysis has been repeated for 20 randomly selected electronic retailers to know if the results are the same for small groups as sample and it is proofed to be similar.

Factor 1 includes on-time product delivery, product representation, customer support, and tracking of shipping status. According to Smith, Bailey, and Brynjolfsson 2000[38], consumers are most worried about receiving the product after online shopping and hence this factor could be a sign of reliability of electronic retailer. The higher the score on Factor 1 is, the more comfortable the consumers are. Ease of ordering, product selection, and the electronic retailer's web site navigation are considered in Factor 2 which all of them are related to shopping convenience. Factor 3 includes the quantity, quality and relevance of product information provided by electronic retailers. Factor 3 includes options and charges of shipping and handling. Factor 5 includes electronic retailers' pricing policy. Therefore, shopping convenience, reliability, product information, shipping and handling, pricing policy could describe the heterogeneity observed in electronic retailers' services.

\subsection{Cluster Analysis}

Electronic retailer then could be categorized based on their scores on the five factors into 3 clusters by using a K-means cluster analysis. Table 3 shows the final cluster centers. The results of ANOVA indicate that the means of all the five factors are significantly different $(\mathrm{p}<0.05)$ across the three clusters.

Cluster 1 with $12.5 \%$ of the electronic retailers is the smallest in Table 3 They are most reliable and are most convenient for shopping but they are not good at providing information on their web sites. Since their price and shipping and handling charges are moderate, they could satisfy the consumers who want what they want. $38 \%$ of electronic retailers belong to cluster 2 . They charge the highest price and provide the least shopping convenience but in economical and flexible shipping and handling, they are number 1 . Their score in reliability and information providing are average. These electronic retailers aim at those consumers who don't care about price and are satisfied through receiving high quality shipping and handling services.

Tables 2. Factor Analysis of E-tailer Services: Rotated component Matrix

\begin{tabular}{|l|c|c|c|c|c|}
\hline & \multicolumn{5}{|c|}{ Component } \\
\hline Variable/Measure & 1 & 2 & 3 & 4 & 5 \\
\hline Ease of Ordering & 0.114 & $\mathbf{0 . 8 3 0}$ & 0.030 & 0.214 & 0.289 \\
Product Selection & 0.167 & $\mathbf{0 . 8 6 3}$ & 0.129 & 0.117 & 0.063 \\
Product Information & 0.108 & 0.107 & $\mathbf{0 . 9 1 0}$ & 0.102 & 0.005 \\
Price & 0.127 & 0.153 & 0.133 & 0.149 & $\mathbf{0 . 9 1 4}$ \\
Web Site Navigation & 0.323 & $\mathbf{0 . 9 1 2}$ & 0.164 & 0.119 & 0.047 \\
On Time Delivery & $\mathbf{0 . 8 1 3}$ & 0.026 & 0.155 & 0.361 & 0.261 \\
Product Representation & $\mathbf{0 . 9 1 3}$ & 0.127 & 0.168 & 0.151 & 0.189 \\
Customer Support & $\mathbf{0 . 9 3 1}$ & 0.112 & 0.165 & 0.229 & 0.304 \\
Tracking & $\mathbf{0 . 8 9 4}$ & 0.117 & 0.421 & 0.165 & 0.119 \\
Shipping and Handling & 0.305 & 0.098 & 0.203 & $\mathbf{0 . 8 5 0}$ & 0.110 \\
\hline Factor Name & Reliability in & Shopping & Product & Shipping and & Pricing Policy \\
\hline
\end{tabular}

Table 3. Cluster Analysis Results: E-tailer positioning

\begin{tabular}{|c|c|c|c|}
\hline E-tailer Features & \multicolumn{3}{|c|}{ Cluster } \\
\hline & 1 & 2 & 3 \\
\hline Reliability & 0.524 & 0.212 & -0.313 \\
\hline Shopping Convenience & 0.720 & -0.831 & 0.531 \\
\hline Product Information & -1.068 & 0.185 & 0.207 \\
\hline Shipping \& Handling & 0.359 & 0.63 & -0.332 \\
\hline Pricing & 0.143 & -0.370 & 0.341 \\
\hline Percent of Sample in Cluster & $12.5 \%$ & $38 \%$ & $49.5 \%$ \\
\hline $\begin{array}{l}\text { Cluster is comprised of } \\
\text { e-tailers }\end{array}$ & $\begin{array}{l}\text { Reliable and } \\
\text { Convenient, } \\
\text { Uninformative }\end{array}$ & $\begin{array}{l}\text { Good in Shipping, } \\
\text { Inconvenient, With High } \\
\text { Price }\end{array}$ & $\begin{array}{l}\text { Convenient, Informative, with } \\
\text { low price and poor shipping }\end{array}$ \\
\hline
\end{tabular}


Cluster 3 includes $49.5 \%$ of electronic retailers which is the largest. The lowest price and deep information are their important characteristics but they are the poorest in reliability shipping and handling and moderate in shopping convenience. It seems that this Group tries to satisfy consumers who seek reasonable prices. What is said about the three clusters shows that they could not be perfect in every aspect. They focus on different target audiences to be unique in their field.

\subsection{Regression Analysis}

Variation in price dispersion results from variation in electronic retailers and market characteristics. The independent variables are as follows:

Electronic retailers characteristics: the following electronic retailers' variables are included in the regression analyses of price dispersal (PRDISP) of each item $\mathrm{i}$ in category $\mathrm{j}$. Dispersion in (1) shopping convenience (CONV), (2) reliability (REL) ,(3) product information (INFO), (4) shipping and handling (SHIP),(5) pricing policy (PRPOL) , (6) inventory position (INV),(7) time of online market entry (TIME), (8) trust (third party certification) (TRUST), and (9) consumer awareness (web traffic and number of referral links) (AWARE). Two sets of regressions are run, one set using ranges and the other set using standard deviations in these characteristics. For showing dispersion for each variable a letter "D" comes before them.

The market characteristics of the following properties are examined in the regression analyses:

- Number of competitors in market, measured by of electronic retailer selling an item (Comp)

- Average price level of the item, a measure consumer involvement (INVOL), and

- Popularity with consumers, measured by a dummy variable indicting the best - selling products (POPLR).

The differences in product category are checked using dummy variables.Each of the five measures of price dispersion on these two classes independent variables and on product category dummies are regressed. (BOOK for BOOK, CD for CD, LTOP for Laptop computer, MOB for Mobile ,MOT for Monitor, MP3 for Mp3 player, and DCAM for digital camera). $\eta$ is an error term.

PRDISPij $=\alpha 1+\alpha 2$ DCONVij $+\alpha 3$ DRELij $+\alpha 4$ DINF Oij $+\alpha 5$ DSHIPij $+\alpha 6$ DPRIPOLij $+\alpha 7$ DINVij $+\alpha 8$ DTIM Eij $+\alpha 9$ DTRUSTij $+\alpha 10$ DAWAREij $+y 1 C O M P i j+y 2 I N$ VOLij $+y 3 P O P L R i j+\lambda 1 B O O K i+\lambda 2 \mathrm{CDi}+\lambda 3 \mathrm{LTOPi}+\lambda 4$ $\mathrm{MOBi}+\lambda 5 \mathrm{MOTi}+\lambda 6 \mathrm{MP} 3 \mathrm{i}+\lambda 7 \mathrm{DCAMi}+\eta \mathrm{ij}$

Linear, semi logarithm and double logarithm models are run for each dependant measure. After being compared, the double logarithm functional form based on Box-Cox (Box and Cox 1964) test is selected. The regression results for the double logarithm model were very similar across dependent measures, therefore, the result of only two dependant measures, i.e. price range and price standard deviation are reported in Table 4. No problem of multicollinearity is revealed through diagnostic statistics. The existence of the heteroscedastictiy is detected by Breusch-pagan test. Table 4 shows the estimated coefficient with their significance levels and model goodness of fit.

Online price dispersion is affected significantly by differences in shopping convenience, reliability, product information, shipping \& handling, and pricing policy. Other electronic retailers' variables such as timing of entry into online market are related to online price dispersion.

By increasing the number of competitors price dispersion decreases, albeit at a diminishing rate. Price dispersion increases with greater consumer involvement or higher price levels, but also at a decreasing rate, thus relative price dispersion declines with greater consumer involvement or higher price levels.

\section{Conclusion}

The effects of variation in electronic retailers and market characteristics on price dispersion among electronic retailers have been examined across items. The electronic retailers' characteristics are the following service characteristics: shopping convenience, reliability in fulfillment, product information provision, economy and flexibility in shipping and handling, pricing policy, inventory position, time of online market entry, trust, and consumer awareness. Studied Market characteristics include number of sellers in market, consumer involvement, and popularity of the category among consumers.

The examination consist three steps. In first step, factor analysis of electronic retailers' characteristics has been performed to define the basic aspects of electronic retailer service. Shopping experience, reliability, information provision, shipping and handling, and pricing policy are the five key factors.

In second step, a cluster analysis of the electronic retailers based on consumers' perception of their services has been performed. The results show that there are three types of electronic retailers aiming different consumer segments. Cluster 1 which is the smallest consists of the most reliable electronic retailers with generally moderate price. Electronic retailers targeting price insensitive consumers with the highest overall price belong to cluster 2 who tries to attract and keep the consumers by providing superior shipping and handling service. Cluster 3 contain 
electronic retailers targeting the price sensitive consumers and are perceived to have the best price and product information, but the worst shipping and handling. Near half of the electronic retailers belong to this cluster. The cluster analysis explains a general image of how electronic retailers' characteristics are related to their overall prices.

In step three, a set of regressions were used to examine the effective elements on price dispersion. Our regression models consistently have adjusted R2 of over $85 \%$ and thus they explain the sources of price dispersion very well.

The standardized coefficient shows that market and electronic retailers' characteristics are the main explanatory variables of price dispersion among electronic retailers. Variation in shopping convenience, reliability, product information provision, economy and flexibility of shipping and handling, and overall pricing, which are all among electronic retailers' characteristics, are related to price dispersion. While variation time of entry into online market affects price dispersion in all the regression models, variation in trust and consumer awareness do not affect price dispersion. An increase in number of competitors which is a market feature, leads to a decrease in price dispersion, but at a descending rate. The higher consumer involvement is, the higher the price dispersion - measured by the range and standard deviation of price - would be. But here the increase is at a slower rate.

Therefore, price dispersion, when measured by the percentage difference or the coefficient of variation of price, decreases with consumer involvement. And price dispersion is not influenced by product popularity.

Table 4. Regression Results of Drivers of Price Dispersion

\begin{tabular}{|c|c|c|c|c|}
\hline $\begin{array}{l}\text { Measure of variation in } \\
\text { e-tailer characteristics }\end{array}$ & \multicolumn{2}{|c|}{$\begin{array}{l}\text { Range of e-tailer } \\
\text { characteristics }\end{array}$} & \multicolumn{2}{|c|}{$\begin{array}{l}\text { Standard Deviation of } \\
\text { e-tailer characteristics }\end{array}$} \\
\hline Measured of price dispersion (dependent variable) & Price Range & Price STD & Price Range & Price STD \\
\hline Adjusted $\mathrm{R}^{2}$ & $89 \%$ & $87 \%$ & $86 \%$ & $87 \%$ \\
\hline Intercept & $-5.41^{b}$ & $-4.67^{\mathrm{a}}$ & $-6.83^{b}$ & $-5.74^{b}$ \\
\hline \multicolumn{5}{|l|}{ E-tailer Characteristics } \\
\hline Shopping convenience & $0.47^{\mathrm{a}}$ & $0.41^{\mathrm{a}}$ & $0.46^{b}$ & $0.39^{\mathrm{a}}$ \\
\hline Reliability in fulfillment & $0.16^{\mathrm{a}}$ & $0.18^{b}$ & $0.15^{b}$ & $0.16^{\mathrm{a}}$ \\
\hline Product information provision & $0.56^{\mathrm{a}}$ & $0.51^{\mathrm{a}}$ & $0.6^{\mathrm{a}}$ & $0.52^{\mathrm{a}}$ \\
\hline Shipping and handling & $0.22^{b}$ & $0.17^{\mathrm{c}}$ & $0.23^{\mathrm{a}}$ & $0.16^{b}$ \\
\hline Pricing Policy & $0.38^{\mathrm{C}}$ & $0.4^{\mathrm{c}}$ & $0.56^{\mathrm{a}}$ & $0.62^{b}$ \\
\hline Timing of online market entry & $0.81^{\mathrm{a}}$ & $0.72^{b}$ & $0.78^{\mathrm{a}}$ & $0.69^{\mathrm{a}}$ \\
\hline Trust/third party certification & -0.07 & -0.1 & 0.03 & 0.01 \\
\hline Consumer awareness & -0.06 & -0.03 & -0.02 & -0.05 \\
\hline \multicolumn{5}{|l|}{ Market characteristic } \\
\hline Number of competitiors & $-0.59^{a}$ & $-0.77^{a}$ & -0.01 & $-0.32^{a}$ \\
\hline Average price (consumer involvement) & $0.84^{\mathrm{a}}$ & $0.85^{b}$ & $0.88^{\mathrm{a}}$ & $0.87^{\mathrm{a}}$ \\
\hline Popularity of product with consumers & 0.01 & 0.05 & 0.05 & 0.02 \\
\hline \multicolumn{5}{|l|}{ Product category differences } \\
\hline $\mathrm{BOOK}$ & $-0.23^{b}$ & $-0.31^{c}$ & $-0.19^{b}$ & $-0.31^{b}$ \\
\hline $\mathrm{CD}$ & $-0.71^{a}$ & $-0.77^{\mathrm{a}}$ & $-0.61^{a}$ & $-0.65^{a}$ \\
\hline Laptop & -0.22 & -0.25 & 0.01 & -0.05 \\
\hline MOBILE & -0.25 & -0.28 & -0.12 & -0.08 \\
\hline MONITOR & $-0.23^{\mathrm{a}}$ & $-0.29^{\mathrm{a}}$ & 0.03 & -0.22 \\
\hline MP3 & $-0.39^{c}$ & $-0.44^{b}$ & -0.1 & -0.17 \\
\hline Digital Camera & -0.18 & -0.21 & 0.08 & -0.06 \\
\hline
\end{tabular}

Dependent and non-dummy independent variables are measured in natural logs.

$\mathrm{P}<0.01^{\mathrm{a}} ; \mathrm{p}<0.05^{\mathrm{b}} ; \mathrm{p}<0.10^{\mathrm{c}}$. Significant effects in bold

To understand the relative effects of the different sets of drivers of price dispersion, we obtained the squares of the standardized coefficients and compared their relative sizes. The results are shown in table 5, which reports the percentages of variation attributable to the three types of independent variables, and to random error. In the four models where price range and price standard deviation are used as the dependent variables, market characteristics account for over $81 \%$ of the variance, while the e-tailer and product characteristics have relatively much lower effects. This is largely due to the relationship between price and the range and 
standard deviation of prices. However, when percentage of difference and coefficient of variation are used as the price dispersion measures, that is, when price range and standard deviation are deflated by the mean price, the relative effect size of market characteristics is significantly reduced to $9 \%-16 \%$ where as the relative effect size of e-tailer characteristics significantly increases to $18-21 \%$. The proportion of variance due to error becomes much larger in this case. This is because scaling the dispersion measure relative to price removes the variation due to involvement (one of the market characteristics) from the regression analysis. However, product characteristics have the smallest effect size. Thus, we conclude that market characteristics and etailer characteristics, especially the former, are the most influential drivers of price dispersion among etailers.

Table 5. The percentage of variance Explained by drivers of price dispersion

\begin{tabular}{|l|l|l|l|l|l|l|l|l|}
\hline $\begin{array}{l}\text { Measure of variation in } \\
\text { e-tailer characteristics }\end{array}$ & \multicolumn{6}{|l|}{ Range of e-tailer Characteristics } & \multicolumn{3}{l|}{} \\
\hline $\begin{array}{l}\text { Measure of price dispersion } \\
\text { (dependent variable) }\end{array}$ & Range & $\begin{array}{l}\text { Percentage } \\
\text { Difference }\end{array}$ & std & CV & Range & $\begin{array}{l}\text { Percentag } \\
\text { Difference }\end{array}$ & std & CV \\
\hline E-tailer characteristics & $4 \%$ & $19 \%$ & $4 \%$ & $18 \%$ & $9 \%$ & $21 \%$ & $5 \%$ & $19 \%$ \\
\hline Market Characteristics & $81 \%$ & $15 \%$ & $78 \%$ & $16 \%$ & $77 \%$ & $9 \%$ & $83 \%$ & $14 \%$ \\
\hline Product Characteristics & $3 \%$ & $14 \%$ & $3 \%$ & $13 \%$ & $3 \%$ & $7 \%$ & $3 \%$ & $14 \%$ \\
\hline Error & $12 \%$ & $52 \%$ & $15 \%$ & $53 \%$ & $11 \%$ & $63 \%$ & $9 \%$ & $53 \%$ \\
\hline
\end{tabular}

\section{Limitations}

The relative immaturity of the internet marketplace is one reason why there were only limited choices of retailers to select from. Although we have identified important drivers of such price dispersion in this study use of cross sectional data may limit the generalizability of our results. Future extension of our

\section{Managerial Implications}

Research on online price dispersion to date has generated several useful implications for pricing strategy. First the finding that online markets are not perfectly competitive, and that price dispersion is expected to persist, suggest that e-tailers can avoid head to head Bertrand price competition with one another. Differentiation is an effective strategy to avoid price competition and it can be achieved through service and non service differentiation. Service differentiation helps e-tailers to target consumers segments with different needs. Non service differentiation, such as third party certification, can help e-tailers to create better consumer awareness and trust. Although the cost of providing better service and creating higher awareness could be nontrivial, it may still be in the interest of the e-tailers to differentiate themselves from others.

Product information provision, one service dimension on the Internet, helps to attract web traffic, but may also heighten consumer price sensivity and study using longitudinal data should produce more robust evidence.

In addition to explaining the drivers of price dispersion, we examined the specific pricing behavior of e-tailers. However, the price regression we used does not consider the competition among the e-tailers and potential effects of the market. Although a detailed analysis of the pricing behavior among etailers is beyond the scope and focus of this study, it will contribute to a better understanding of this phenomenon.

promote free riding. This suggests a segmentation strategy based on information provision. Thus, providing great information with low prices is a useful strategy to attract and lock in consumers who are inclined to search extensively, while providing low information with high price is helpful to obfuscate consumer search and to win the loyal and uniformed consumers. Different online sellers commonly appear to adopt one or the other of these strategies.

\section{Future Work}

Analyzing price data can be used in other internet markets, for different retailers, different titles, and for a different time period. In fact, the data should be compared with such analysis to increase the robustness of the insights.

The data in this thesis opens up new opportunities for further data analysis. More data collection using more retailers and titles can give greater insight into the questions of how this data is indicative of Internet commerce in the future or an aberration of the present. 
Most importantly, data collection that increases the time window examined can give insight into the progression of changes that characterize Internet commerce development.

\section{References}

[1] Baye, J. Morgan. "Information gatekeepers on the Internet and the competiveness of Homogenous product markets", The American Economic Review, 2001,91(3), 454-747.

[2] X. Pan,B. B. T. Ratchford, and Shankar, "Can price dispersion in online markets be explained by differences in e-tailer service quality?",Journal of the academy of marketing Science, 2002a ,30(4), 443-456.

[3] X. Pan, B.T. Ratchford, and V. Shankar, "Why are not the prices of the same item at Me. Com and You.com?" Drivers of price dispersion among e-tailers (working paper)". College Park: University of Maryland, 2003a.

[4] G. Stigler, "The economics of information", journal of political economy,1961, 69 (3): 213-225.

[5] A. Fishman, "Search Technology, Staggered PriceSetting, and price Dispersion", The American Economic Review, 1992, 82 (1); 287-298.

[6] Dana, James, "Equilibrium price dispersion under demand uncertainty: The role of costly capacity and market structure",Rand Journal of economics, 1999, 30 (4): 632-660.

[7] E, Clemon, H. I1-Horn, and L. Hitt, "The nature of competition in Electronic markets: An Empirical Investigation of Online Travel Agent Offerings", The Wharton School of the University of Pennsylvania, 1998.

[8] V. Shankar, A. Rangaswamy, and M. Pusateri, The online Medium and customer price sensivity (working paper). College Park: University of Maryland,(2001).

[9] Smith, Michael, J. Bailey, and E. Brynjolfsson, "Understanding Digital Markets: Review and Assessment," E. Brynjolfsson and B. Kahin, eds, Understanding the Digital economy, MIT Press, Cambridge, MA,(2000).

[10] X. Pan, B. T. Ratchford, and V. Shankar, "Can Price Dispersion in online markets be explained by differences in e-tailer service quality?" Journal of the academy of marketing Science,2002, 30(4), 443-456.

[11] Smith, Michael, J. Bailey, and E. Brynjolfsson, "Understanding Digital Markets: Review and Assessment," E. Brynjolfsson and B. Kahin, eds, Understanding the Digital economy, MIT Press, Cambridge, MA,(2000).

[12] X. Pan,. B. T. Ratchford, and V. Shankar, "Can Price Dispersion in online markets be explained by differences in e-tailer service quality?" Journal of the academy of marketing Science", 2002,30(4), 443-456.

[13] Smith, Michael, J. Bailey, and E. Brynjolfsson, "Understanding Digital Markets: Review and Assessment," E. Brynjolfsson and B. Kahin, eds, Understanding the Digital Economy, MIT Press, Cambridge, MA,2000.

[14] Smith, Michael, J. Bailey, and E. Brynjolfsson,
"Understanding Digital Markets: Review and Assessment," E. Brynjolfsson and B. Kahin, eds, Understanding the Digital economy, MIT Press, Cambridge, MA,2000.

[15] V. Shankar, A. Rangaswamy, and M. Pusateri, "The online Medium and customer price sensivit (working paper)", College Park: University of Maryland, 2004.

[16] Burdett and M. Coles, "Steady state price distribution in a noisy search equilibrium" journal of economic theory,1997, 72(1):1-32.

[17] Schmalensee, Richard, "Product Differentiation Advantages of Pioneering Brands" American Economic Review, 1982,72(3):349-365.

[18] I. Geyskens, K. Gielens and G, Marnik, "Establishing the internet channel: Short term pain but long-term Gain?", forthcoming, Journal of marketing,2001.

[19] Smith, Michael and E. Brynjolfsson, "Customer Decision-Making at an Internet Shopbot: Brand Still Matters," Quarterly Journal of Economics, 2001,49(4): 541-558.

[20] Shankar, Smith, and A. Rangaswamy, "Customer Satisfaction and loyalty in online and offline Envirronments," International Journal of Research in Marketing, forthcoming, 2003.

[21] Baye, and J. Morgan,. "Information Gatekeepers on the Internet and the Competitiveness of Homogeneous Product Markets", The American Economic Review, 2001,91(3), 454-474.

[22] Carlson, John and P. McAfee,"Discrete Equilibrium price dispersion" journal of political economy, 1983,91(3): 480-493.

[23] Carlson, John and P. McAfee,"Discrete Equilibrium price dispersion", journal of political economy, 1983,91(3): 480-493.

[24] B. Dahlby, and D. West, "Price dispersion in an automobile Insurance Market”, Journal of political Economy, 1986, 94(2):418-438.

[25] Cohen, "The impact of brand selection on price competition- a double edged sword",applied Economics, 2000, 32:601-609.

[26] J. Kujala, and M. Johnson,"Price knowledge and search Behavior for Habitual, Low Involvement Food Purchase, "Journal of Economic Psychology, 1993, 14(2):249-265.

[27] Moorthy, Sridhar,and D. Talukdar, "Consumer Information search revisited",Journal of Consumer research, 1997:263-277.

[28] Cohen, and Marcel, "Linking Price Dispersion to product Differentiation-Incorporate Aspects of customer Involvement,"Applied Economics, 1998, 30:829-835.

[29] Pratt, John, D. Wise, and R. Zeckhauser, "Price Differences in Almost Competitive Markets," Quarterly Journal of Economics, 1979: 189-211.

[30] Clemons, Eric, I1-Horn-Hann, and L. Hitt, "The Nature of Competition in Electronic Markets: An Emprical Investigation of Online Travel Agent Offerings", The 
Wharton School of the University of Pennsylvania, 1998.

[31] F. Ancarani, and V. Shankar. "Price Levels and Price Dispersion Within and Across Multiple Retailer Types: Further Evidence and Extension". Journal of Academy of Marketing Science, 2004,32(2), 176-187.

[32] F. Ancarani, and V. Shankar. "Price Levels and Price Dispersion Within and Across Multiple Retailer Types: Further Evidence and Extension". Journal of Academy of Marketing Science, 2004,32(2), 176-187. 